\title{
Wybrane tendencje w ksztaltowaniu architektury kwartałów zabudowy mieszkaniowej Europy w pierwszych dekadach XXI wieku
}

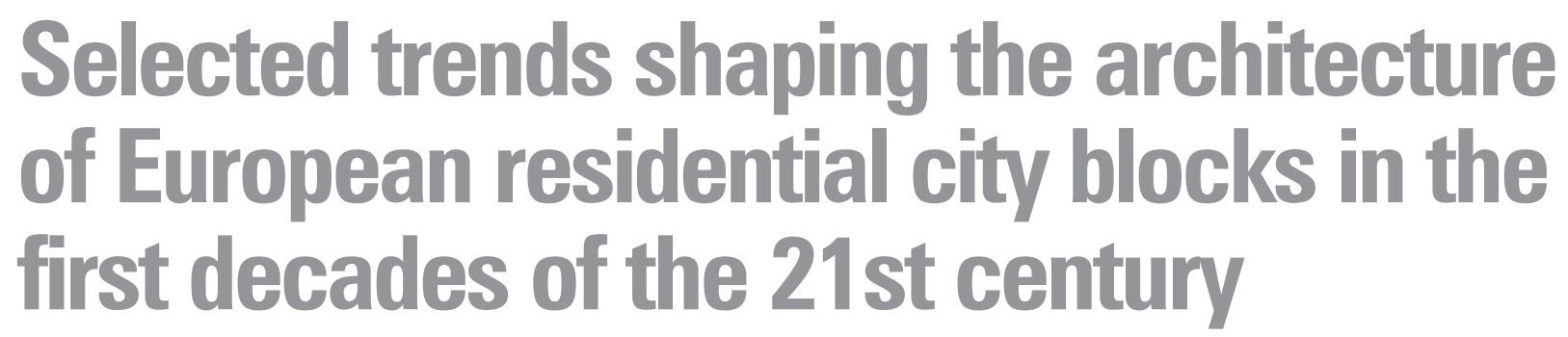

\begin{abstract}
Streszczenie
Tematem artykułu jest architektura współcześnie realizowanych kwartałów zabudowy mieszkaniowej z różnych części Europy. Celem artykułu jest wskazanie i opisanie wybranych tendencji estetycznych towarzyszących kształtowaniu ich formy. Główny temat artykułu koncentruje się wokół kwartałów zabudowy mieszkaniowej z okresu pierwszych dwóch dekad XXI wieku. Badania pozwoliły wskazać wyraziste cechy, które dominują i zarazem definiują estetyczny wyraz i charakterystyczne elementy architektonicznej idei dzisiejszego kwartału zabudowy mieszkaniowej. Podstawowymi metodami badawczymi są analizy i studia wybranych przypadków. Wyniki badań wskazują na zróżnicowanie założeń przestrzennych i estetycznych, co pomaga w odkrywaniu i poszukiwaniu nowych typologicznych rozstrzygnięć, wpływających na jakość zamieszkiwania. Badania służą także do formułowania teoretycznych podstaw projektowania tego rodzaju zabudowy, a także pozwalają prognozować dalsze kierunki rozwoju idei kwartału zabudowy mieszkaniowej dla niedalekiej przyszłości. Sformułowane wnioski koncentrują się na ujawnieniu pewnej oryginalności i atrakcyjności formy jako wspólnego wyznacznika występującego wśród panującego pluralizmu postaw twórczych w dzisiejszej architekturze.
\end{abstract}

\section{Abstract}

The subject of the article is the architecture of contemporary residential blocks from different parts of Europe. The aim of the article is to indicate and describe selected aesthetic trends related to the design of their form. The main topic of the article concerns residential city blocks from the first two decades of the $21^{\text {st }}$ century. The research has allowed indicating clear features that dominate and at the same time define the aesthetic expression and characteristic elements of the architectural idea behind contemporary residential city blocks. The principal research methods are analysis and case studies. The results of the research indicate a variety of spatial and aesthetic assumptions, which aids in discovering and searching for new typological solutions that affect the quality of habitation. The research also serves to formulate the theoretical basis for the design of this type of development, and allows one to forecast further directions for the advancement of the idea of a residential city block in the foreseeable future. The findings focus on revealing certain originality and attractiveness of the form as a common determinant of the prevailing pluralism of creative attitudes in modern architecture.

Słowa kluczowe: kwartał zabudowy mieszkaniowej Europy, kwartał wertykalny, architektura mieszkaniowa w XXI wieku, kameralność zabudowy kwartałowej, zabudowa wielorodzinna

Keywords: European city block, vertical city block, residential architecture in the 21-st century, intimacy of a city block, multi-family buildings

\section{Wprowadzenie}

Chcąc wskazać główne tendencje w projektowaniu kwartałów zabudowy mieszkaniowej pierwszych dekad XXI wieku, należy sięgnąć do architektonicznej istoty tej formy mieszkalnictwa. O ile historycznie rozumiane kwartały zabudowy miejskiej powstawały z przylegających do siebie kamienic, które realizowano na odrębnych, niewielkich działkach, często z zabudową oficynową i z przestrzeniami kameralnych podwórzy, o tyle we współczesnych kwartałach zabudowy mieszkaniowej, projektowanych

\section{Introduction}

In order to indicate the key trends in the design of residential city blocks in the first decades of the twenty-first century, one should turn to the architectural essence of this form of housing. While historically understood city blocks were formed from adjacent tenement houses, which were built on separate, small plots of land, often with outbuildings and intimate courtyard spaces, contemporary city blocks, designed on larger plots of land, have developed a larger semi-private interior, serving the community

* Dr inż. arch. Przemysław Bigaj, Zakład Architektury Mieszkaniowej i Kompozycji Architektonicznej, Instytut Projektowania Architektonicznego, Wydział Architektury Politechniki Krakowskiej / Przemysław Bigaj, Dr inż. arch., Chair of Housing and Architectural Composition, Institute of Architectural Design, Faculty of Architecture, Cracow University of Technology, e-mail: pbigaj@pk.edu.pl, ORCID: 0000-0003-0808-6286 

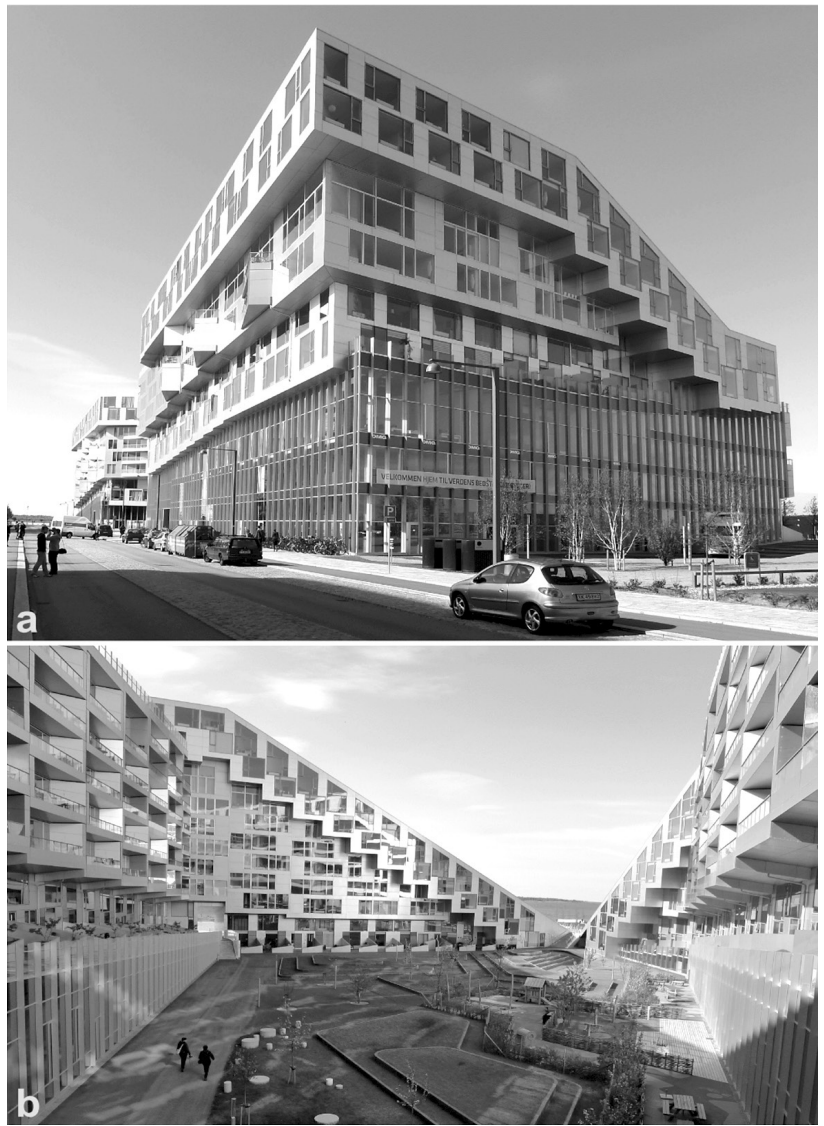

na większych parcelach, wykształciła się przestrzeń obszerniejszego wnętrza o charakterze półprywatnym, służąca wspólnocie mieszkańców, wpływając bezpośrednio na jakość środowiska mieszkaniowego. Dawny kwartał zabudowy miejskiej cechowała także różnorodność estetyczna poszczególnych budynków wchodzących w jego skład. Dzisiejsze kwartały tworzą zazwyczaj jednolitą pod względem estetycznym całość, będącą niejednokrotnie wynikiem pewnych tendencji do unifikacji rozwiązań funkcjonalno-przestrzennych i techniczno-materiałowych, a także cechuje je realizacyjna i projektowa spójność. To co wyróżnia współczesne od tradycyjnych kwartałów, to zastosowane środki wyrazu, oryginalność formy oraz idea tworzenia różnych gradacji przestrzeni dla dzisiejszej wspólnoty mieszczan. Rolą zabudowy kwartałowej pozostaje wciąż tworzenie zwartej tkanki miejskiej, która dzieli przestrzenie na publiczne (place, ulice, skwery, itd.), półprywatne (wnętrza kwartałów, podwórza miejskie, atria) i w końcu prywatne - związane bezpośrednio z zamieszkiwaniem.

\section{Tendencje w kształtowaniu architektury współczes- nych kwartałów zabudowy mieszkaniowej}

2.1. Kwartał w typologii zabudowy mieszkaniowej Jan Pallado w publikacji Typologia zabudowy mieszkaniowej, zabudowę kwartałową zaliczył do jednego z czterech podstawowych typów zabudowy wielorodzinnej, tuż obok zabudowy punktowej, odcinkowej i liniowej, a mianowicie do zabudowy płaszczyznowej. Typolo-

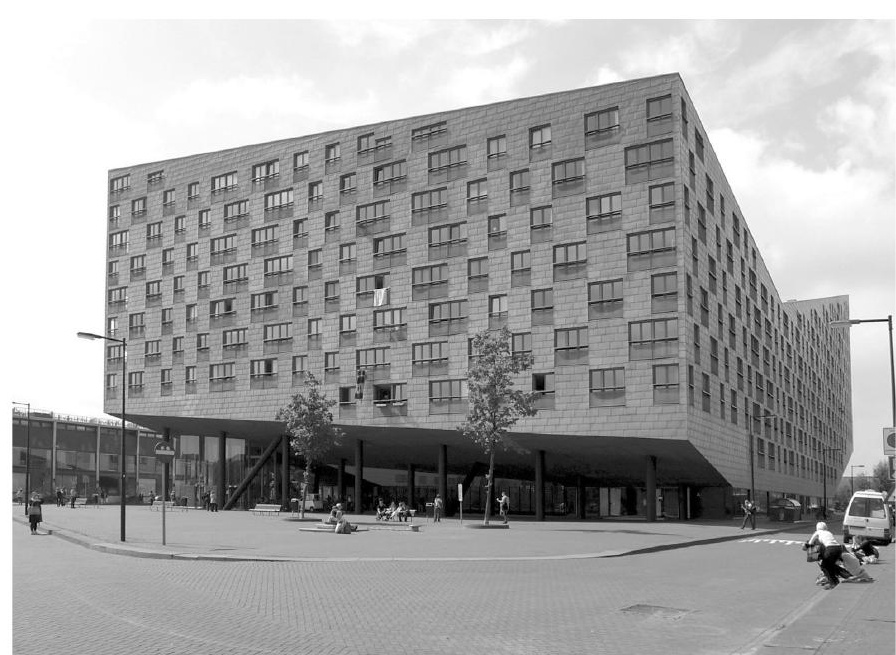

II. 1. The Whale, Amsterdam, Holandia, 2000, de Architekten Cie - Frits van Dongen, źródło/autor: P. Bigaj

III. 1. The Whale, Amsterdam, the Netherlands, 2000, de Architekten Cie - Frits van Dongen, source/author: P. Bigaj.

II. 2. 8 Tallet, Ørestad Syd, Kopenhaga, Dania, 2010, BIG - Bjarke Inge/s Group: a) widok ogólny na część mieszkalno-usługową; b) jedno z wnętrz kwartału 8 Tallet. źródło/autor: P. Bigaj

III. 2. 8 Tallet, Ørestad Syd, Copenhagen, Denmark, 2010, BIG - Bjarke Inge/s Group: a) a general view of the residential and commercial part; b) one of the interiors of the 8 Tallet city block, source/author: P. Bigaj

of residents, and thus directly influencing the quality of the residential environment. The former city block was also characterised by the aesthetic diversity of individual buildings that made up its whole. Contemporary blocks, in turn, tend to form an aesthetically uniform whole, which is often the result of certain tendencies to unify functiospatial, and technical and material solutions, and they are characterised by design and implementation cohesion. What distinguishes the contemporary blocks from the traditional ones are the adopted means of expression, originality of form and the idea of creating various gradations of space for the modern bourgeois community. The role of city block development is still to create a compact urban fabric that divides space into public (squares, streets, plazas, etc.), semi-private (interiors of the city blocks, city courtyards, atria) and finally private spaces-the latter being directly related to habitation.

\section{Trends shaping the architecture of contemporary residential city blocks}

2.1. The city block within the housing typology In his publication Typologia zabudowy mieszkaniowej (Typology of residential building development), Jan Pallado classified the city block as one of the four basic types of multi-family development, along with detached, semi-detached, and linear buildings, namely into the block perimeter structures. Typologically, it covers a much larger group of forms than the commonly understood city block. Pallado ex- 
gicznie, obejmuje ona znacznie większą grupę form niż powszechnie rozumiana zabudowa kwartałowa. Jak wyjaśnia Pallado: Zabudowa płaszczyznowa to zespót budynków stykających się lub połączonych ze sobą, tworzących zabudowę o znacznej długości i szerokości oraz stosunkowo małej wysokości. Budynki usytuowane są często w liniach zabudowy ulic obsługujących kwartat, tworząc zwartą strukturę z wewnętrznymi dziedzińcami. Dziedzińce te spełniają funkcje doświetlające oraz stanowią wyraźnie zdefiniowane przestrzenie sąsiedzkie. Zabudowa płaszczyznowa rzadko pojawia się w typologii zabudowy wielorodzinnej jako całościowa grupa, częściej w postaci osobnych grup typologicznych, takich jak na przykład zabudowa dziedzińcowa, kwartałowa, grzebieniowa lub fiszbinowa (Pallado, 2016, 18). Do zabudowy płaszczyznowej autor zaliczył tu także zabudowę meandryczną, rozgałęzioną oraz tzw. domy-wzgórza. Wśród zabudowy płaszczyznowej wskazano natomiast kilka rodzajów kwartałów, a mianowicie kwartał zamknięty, półzamknięty, półotwarty i otwarty (Pallado, 2016, 19). Wiele z wymienionych tu innych grup, mieszczących się w ramach zabudowy płaszczyznowej, choć nie będących typowo rozumianymi kwartałami zabudowy mieszkaniowej, ma jednak wyraźne cechy form wskazujące na bezpośrednie konotacje z tego rodzaju zabudową. Wynikają one z mniej lub bardziej wykształconych (zazwyczaj otwartych) form dziedzińców, wnętrz i cofnięć, nadających ów "sąsiedzki" charakter tak uzyskanym przestrzeniom. Realizacje z pierwszych dekad XXI wieku jeszcze bardziej pogłębiają typologiczny chaos form poprzez rozrzeźbione, często ekspresyjne i zróżnicowane bryły. Marcin Głuchowski w pracy Ku współczesnemu kwartałowi architektury mieszkaniowej, w poszukiwaniach przyjaznej przestrzeni towarzyszącej architekturze wielorodzinnej, dokonuje w analizach form współczesnych kwartałów zabudowy mieszkaniowej systematyki, opartej o kryteria ich regularności i nieregularności, jednolitości i złożoności oraz także uwzględnia zagadnienie otwarcia i zamknięcia form kwartału (Głuchowski, 2015, 26, 137-143). Klasyfikacja ta dobrze oddaje tendencje i zjawiska przestrzenne typowe dla kształtowania form kwartałów zabudowy mieszkaniowej, realizowanych w pierwszych dwóch dekadach XXI wieku.

2.2. Kwartał zabudowy mieszkaniowej pierwszych dekad XXI wieku - charakterystyka wybranych tendencji

2.2.1. Kwartał zabudowy mieszkaniowej jako ikona miejsca Dziś pracownie architektoniczne starają się oryginalnością zaproponowanej idei architektonicznej nie tylko przykuć uwagę widza, ale i wytyczyć nowe trendy towarzyszące projektowaniu współczesnych kwartałów. Za jedną z ikon architektury mieszkaniowej początków nowego milenium można uznać kwartał The Whale (il. 1) z Amsterdamu (Holandia, 2000), według projektu de Architekten Cie (Fernandez Per, Mozas, 2006, 210-215). Budynek dzięki charakterystycznym ukośnym przełamaniom i podniesieniom, dającym wgląd we wnętrze kwartału, tworzy kontrastujący z sąsiednią zabudową obiekt, wyróżniający się plains that a block perimeter structure is a group of buildings that contact or are connected to each other, forming a building of considerable length and width and relatively low height. The buildings are often located in the development lines of streets serving the city block, creating a compact structure with internal courtyards. These courtyards provide access to insolation and represent clearly defined neighbouring spaces. The block perimeter structure rarely appears in the typology of multi-family buildings as a complete group, more often in the form of separate typological groups, such as a courtyard, urban block, comb or whalebone structure (Pallado, $2016,18)$. The author also included the meandering, branched building development and the so-called "house-hill" buildings among the block perimeter structures. Among the block perimeter structures, several types of urban blocks were indicated, namely closed, semi-closed, semi-open and open ones (Pallado, 2016, 19). A number of other groups listed here, which are part of the block perimeter structure, although not being typically understood as residential city blocks, have nevertheless clear features of the forms indicating direct connotations with this type of development. These result from more or less developed (usually open) forms of courtyards, interiors and recesses that lend this "neighbourly" character to the spaces thus obtained. The works from the first decades of the twenty-first century exacerbate the typological chaos of forms even further through sculpted, often expressive and diverse structures. In his work Ku współczesnemu kwartałowi architektury mieszkaniowej (Towards a modern residential city block) pursuing a friendly space that would accompany multi-family architecture, Marcin Głuchowski analyses the forms of contemporary residential city blocks and provides their taxonomy based on the criteria of their regularity and irregularity, uniformity and complexity, including the issue of the opening and closing of city block forms (Głuchowski, 2015, 26, 137-143). This classification perfectly captures the spatial trends and phenomena typical of the shaping of residential city blocks constructed in the first two decades of the twenty-first century.

2.2. The residential city block in the first decades of the twenty-first century - characteristics of selected trends

2.2.1. The residential city block as an icon of a place At present, not only do architectural studios strive to catch the audience's attention with the originality of the proposed architectural ideas, but they also try to establish new trends that would accompany the design of contemporary city blocks. The Whale city block (ill. 1) in Amsterdam (the Netherlands, 2000) designed by de Architekten Cie (Fernandez Per, Mozas, 2006, 210-215) may be regarded as one of the icons of residential architecture from the beginning of the new millennium. Owing to the characteristic slants and elevations that provide an insight into the interior 
skalą i dynamiką formy, mogącą przywodzić wyobrażenie tytułowego "wieloryba" unoszącego się nad zrewitalizowaną dzielnicą portową Borneo-Sporenburg. Bjarke Ingels Group (BIG) może z kolei poszczycić się budynkiem 8 Tallet (il. 2a) z dzielnicy Kopenhagi - Ørestad Syd (Dania, 2010), którego duże w skali założenie powstało w wyniku reinterpretacji formy typowego kwartału zabudowy, opierającego się na planie zbliżonym do tytułowej „8". Dzięki temu uzyskano aż dwa wnętrza w ramach jednego obiektu (il. 2b). Oprócz formy aspirującej do miana lokalnej ikony, budynek ten stał się poligonem doświadczalnym dla nowych rozwiązań związanych z jakością środowiska mieszkaniowego. Markthal to jeden z najbardziej ikonicznych budynków holenderskiego biura projektowego MVRDV (Winy Maas, Jacob van Rijs, Nathalie de Vries) ostatnich lat. Zrealizowany w 2014 roku w Rotterdamie (Holandia), jest typologicznym ewenementem, wymykającym się opisywanym systematykom budynków. Forma budynku tworzy rodzaj łuku, którego strukturę wypełnia, dominująca funkcja mieszkalna. Ze względu na wewnętrzny plac handlowy, zadaszony przesklepieniem, można zakwalifikować ten rodzaj zabudowy jako nietypowy kwartał mieszkalny ze zintegrowanymi funkcjami handlowymi i rekreacyjnymi. Jest to nowatorskie spojrzenie na współczesną przestrzeń tradycyjnego rynku miejskiego i otaczającą go funkcją mieszkalną. Jan Pallado określa ten rodzaj budynku jako Dom-piazza - nowy typ zadaszonej przestrzeni miejskiej, integrującej część mieszkalną z innymi częściami budynku pod względem funkcjonalnym i wizualnym (Pallado, 2014, 132-133). Przytoczenie tu zaledwie kilku czołowych i powszechnie rozpoznawalnych przykładów nietypowych budynków zaświadcza, iż kwartał mieszkaniowy może z powodzeniem stać się wdzięcznym tematem do realizacji oryginalnych i atrakcyjnych form o ikonicznym charakterze. Zjawisko to z każdym rokiem przynosi nowe interesujące przykłady i rozstrzygnięcia, które przybierają postać pewnej tendencji koncentrującej się na ideowej i estetycznej oryginalności kształtu, oraz wskazuje na intensyfikacje i rozwój dalszych eksperymentów przestrzennych z formami kwartałów zabudowy mieszkaniowej w niedalekiej przyszłości.

\subsubsection{Idea "kwartału wertykalnego"}

Biuro MVRDV stało się laboratorium doświadczalnym, którego realizacyjne efekty skupiają się na odkrywaniu w zabudowie kwartałowej nowych rozstrzygnięć przestrzennych na miarę ikon współczesnej zabudowy mieszkaniowej. Do jednej z takich ikon można zaliczyć budynek Mirador (Sanchinarro, Madryt, Hiszpania, 2005, współpraca Blanca Lleó) (Fernandez Per, Mozas, 2006, 256-263). Zamysł, który przyświecał autorom projektu wprowadza ideę obróconego do pionu kwartału, w wyniku czego powstaje wspólna przestrzeń społeczna wnętrza na wysokości 40 metrów (il. 3b). Takie działanie pozwoliło uzasadnić wzniesienie pośród kwartałowej zabudowy wertykalnej formy, która ma stworzyć ikoniczny kontrapunkt dla otoczenia. Nieco inny charakter "wertykalnego kwartału” zyskał budynek Parkrand (Geuzenveld, Amsterdam, Holandia, 2006) składa- of the block, the building constitutes a structure contrasting with the adjacent buildings, distinguished by the scale and dynamics of its form that may evoke the image of the titular "whale" floating over the redeveloped harbour district of Borneo-Sporenburg. The Bjarke Ingels Group $(B / G)$, in turn, can boast the 8 Tallet building (ill. 2a) in the district of Copenhagen- Ørestad Syd (Denmark, 2010), whose large-scale design was established as a result of a reinterpretation of the form of a typical city block, based on a plan similar to the titular "8". Consequently, as many as two interiors within one structure could be obtained (ill. 2b). Apart from the form aspiring to be a local icon, this building has become a testing ground for new solutions related to the quality of the residential environment. The Markthal has been one of the most iconic buildings of the Dutch design studio MVRDV (Winy Maas, Jacob van Rijs, Nathalie de Vries) in recent years. Constructed in Rotterdam (the Netherlands) in 2014, it is a typological phenomenon, evading known building systems. The form of the building forms a kind of arch, whose structure is filled with a dominant residential function. Owing to its internal market square, covered with glazed roofing, this type of development can be classified as an unusual residential city block with integrated commercial and recreational functions. This is an innovative approach to the contemporary space of the traditional city square and the surrounding residential function. Jan Pallado describes this type of building as House-Piazza - a new type of sheltered urban space that integrates the residential part with the other parts of the building in terms of functionality and visual aspects (Pallado, 2014, 132-133). Mentioning here only a few leading and universally recognisable examples of unusual buildings proves that the residential city block can successfully become a graceful subject for the creation of original and attractive forms with an iconic character. This phenomenon brings new interesting examples and solutions every year, which take the form of a certain trend focusing on the ideological and aesthetic originality of the shape, and indicates the intensification and development of further spatial experiments with the forms of residential city blocks in the foreseeable future.

\subsubsection{The idea of a "vertical city block"}

The MVRDV studio has become an experimental laboratory whose construction results concentrate on discovering new spatial solutions in the city block that would match up to the icons of modern residential buildings. One such icon is the Mirador building (Sanchinarro, Madrid, Spain, 2005, cooperation with Blanca Lleó) (Fernandez Per, Mozas, 2006, 256-263). The idea that guided the authors of the design introduces the idea of a vertically turned city block, as a result of which a common social space of the interior is created at a height of 40 metres (ill. 3b). Such an action allowed one to justify the erection of the vertical form in the midst of the city block, which is to create an iconic counterpoint for the surroundings. 
(Fernandez Per, Mozas, Arpa, 2007, 170-175). Dzielnice realizowane w oparciu o tego typu kameralną zabudowę tworzą estetycznie zróżnicowane struktury, które nie przytłaczają monotonią znaną z dużych i architektonicznie jednorodnych założeń osiedlowych. Wyraźna kompozycja formy niewielkich kwartałów tworzy korzystne relacje pomiędzy kubaturą budynku a wykształconą przestrzenią, tworząc harmonię i czytelną hierarchię miejskich wnętrz. Jest to istotne w kształtowaniu tożsamości przestrzennej w oparciu o proste zabiegi kompozycyjne. Skala założenia kwartałowego jest decydującą determinantą wpływającą na akceptację i przyjazny odbiór półprywatnego wnętrza.

2.2.4. Swobodny albo uporządkowany charakter estetyki fasad w dzisiejszych kwartałach zabudowy mieszkaniowej

Wśród głównych zabiegów estetycznych towarzyszących powstawaniu dzisiejszego wyrazu architektonicznego budynków mieszkalnych jest unikanie takich cech w sposobie komponowania form obiektów wielorodzinnych, które mogą w znaczący sposób wskazywać czy też eksponować zróżnicowany status materialny mieszkańców w obrębie danego zespołu zabudowy. Wskazuje na to zjawisko Jan Pallado (Pallado, 2014, 48), jako pewien rezultat istnienia społeczeństwa demokratycznego, co znajduje także swoje odzwierciedlenie $w$ architekturze mieszkaniowej. Jest to widoczne w rozwiniętych krajach zachodniej Europy, gdzie często realizowane inwestycje przybierają socjalny model kształtowania mieszkalnictwa i wynikający z niego wyraz estetyki. Przykładem obrazującym to zjawisko jest hiszpański budynek Celosia (MVRDV i Blanca Lleó, Madryt, 2009, il. 5), gdzie regularne, na planie prostokąta założenie, z czytelnie wyodrębnionym wnętrzem, uzupełniono perforacjami kwartału na różnych kondygnacjach (Fernandez Per, Mozas, Arpa, 2009, 198-217). Urządzono w nich dodatkowe przestrzenie integrujące życie mieszkańców. Stosowanie pewnej, zamierzonej swobody czy naprzemienności otworów i tarasów tylko pozornie wprowadza poczucie ażurowości i przypadkowości tak ustalonej kompozycji. Spoistości formy towarzyszą zabiegi estetyczne polegające na unikaniu harmonicznej osiowości znanej z historycznych budynków. Wystarczy już prosty zabieg, aby na piętrach o tym samym rozkładzie pomieszczeń stworzyć możliwość zmiany rozkładu okien na elewacji, żeby wprowadzić ów efekt pozornej przypadkowości czy kompozycyjnej naprzemienności otworów. Wskazać tu można inne madryckie budynki, których architekturę ukształtowano wg tej zasady, jak np. kwartał z 2005 roku, tj. Housing Villaverde, zaprojektowany w pracowni David Chipperfield Architects (Fernandez Per, Mozas, 2006, 360-365), czy kwartał ze 132. mieszkaniami z 2008 roku, zaproponowany przez pracownię Aguinaga y Asociados Arquitectos (Bulevar de la Naturaleza, Ensanche de Vallecas) (Fernandez Per, Mozas, Arpa, 2009, 88-95). Niejako w opozycji do tej swobody komponowania elewacji w kwartałach zabudowy mieszkaniowej istnieją także tendencje do tworzenia geometrycznie rygorystycznych fasad w oparciu o zasadę osiowości, interiors were constructed, such as Zinkhuset (Holsre Arkitekter A/S, 2008, ill. 4a, 4b) and Northern Lights (C.F. Møller Architects, 2006) (Fernandez Per, Mozas, Arpa, 2007, 170-175). The quarters built on the basis of such an intimate building development create aesthetically diverse structures that do not overwhelm one with the monotony known from large and architecturally homogeneous housing estates. The distinctive composition of the form of small city blocks creates advantageous relations between the massing of the building and the developed space, creating harmony and a clear hierarchy of urban interiors. This is crucial in shaping spatial identity based on simple compositional procedures. The scale of the city block is a decisive determinant influencing the acceptance and friendly reception of the semi-private interior.

2.2.4. Free or orderly facade aesthetics in contemporary residential city blocks

Among the main aesthetic measures related to the creation of modern architectural expression of residential buildings is the avoidance of such features in the way of composing forms of multi-family buildings that can significantly indicate or expose the diverse material status of residents within a given complex. Jan Pallado (Pallado, 2014, 48) points to this phenomenon as a result of the existence of a democratic society, which is also reflected in housing architecture. This is visible in the developed countries of Western Europe, where projects often adopt a social model of housing development and the resultant aesthetic expression. One example illustrating this phenomenon is the Spanish Celosia building (MVRDV and Blanca Lleó, Madrid, 2009, ill. 5), where a regular complex constructed on a rectangular plan, with a clearly separated interior, was complemented by perforations of the block on different floors (Fernandez Per, Mozas, Arpa, 2009, 198-217). Additional spaces were arranged inside them to integrate the life of the residents. The use of certain, intended freedom or alternation of openings and terraces only seemingly introduces a sense of openwork and randomness of this compositional arrangement. The cohesiveness of form is accompanied by aesthetic measures consisting in avoiding the harmonious axiality known from historical buildings. Such a simple procedure as the possibility of changing the arrangement of windows on the façade on the floors possessing the same room distribution was enough to introduce this effect of apparent randomness or compositional alternation of openings. Other buildings in Madrid whose architecture was shaped according to this principle can be listed here, such as the city block from 2005, i.e. Housing Villaverde, designed by David Chipperfield Architects (Fernandez Per, Mozas, 2006, 360-365), and the city block with 132 flats from 2008 designed by Aguinaga y Asociados Arquitectos (Bulevar de la Naturaleza, Ensanche de Vallecas) (Fernandez Per, Mozas, Arpa, 2009, 88-95). In opposition to this freedom in the composition of facades in residen- 


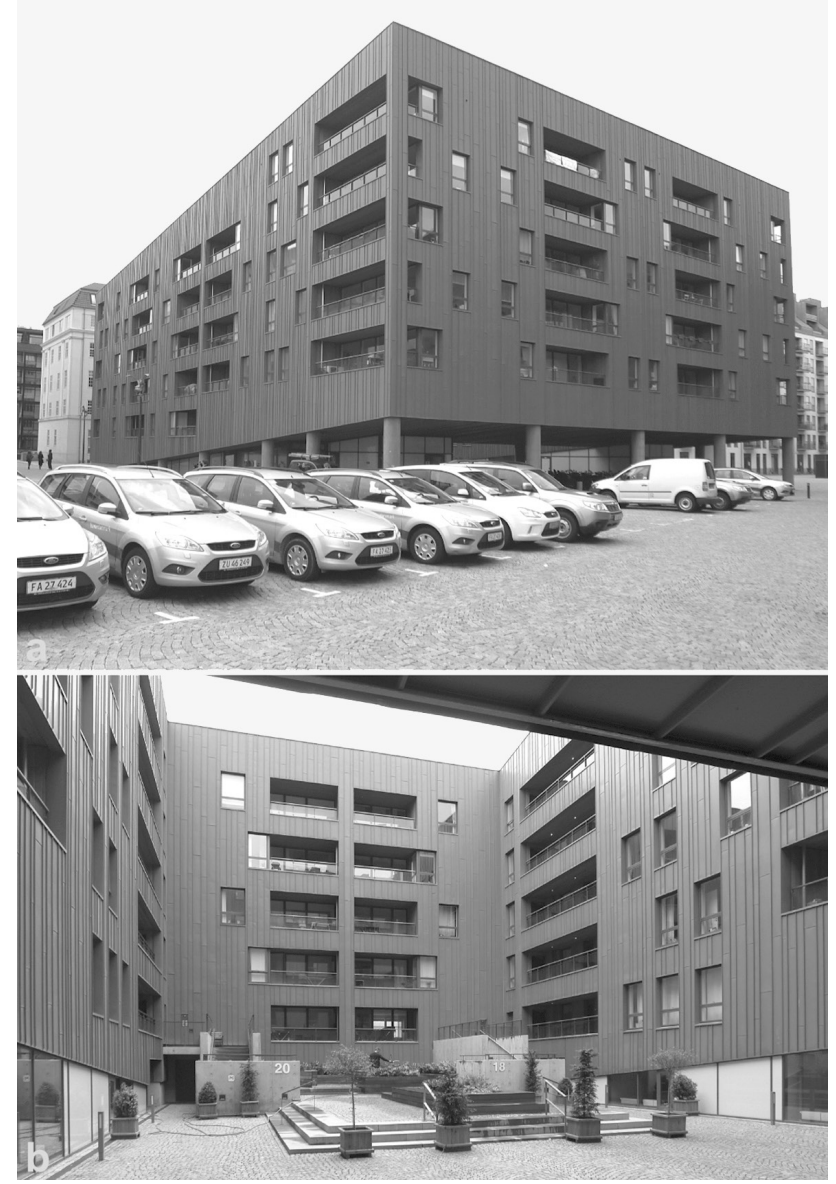

a także wprowadzanie rytmiczności czy powtarzalność elementów otworów, loggii, balkonów, itp., podkreślając tym samym wyraz zaplanowanego ładu i porządku układu. Zjawisko to jest częściowo związane z kontynuacją neoracjonalistycznych ruchów, reprezentowanych przez takie postacie architektury jak: Aldo Rossi, Alvaro Siza, Mario Botta, czy Mathias Ungers. Wśród dzisiejszych racjonalistycznych tendencji kształtujących uporządkowany i rygorystyczny obraz architektury kwartałowej wymienić można takie przykłady zabudowy jak: zespół budynków Piazza Céramique, o charakterze niewielkich kwartałów z zadaszonymi wnętrzami, zaprojektowanych przez Jo Janssen Architecte w Mastricht (Holandia, 2013), czy założenie kwartałowe La Fortezza Mario Botty (Mastricht, Holandia, 2000) o cylindrycznej formie z kwadratowym wnętrzem dziedzińca.

2.2.5. Przywracanie „kamienicowego" układu architekturze mieszkaniowej w dzisiejszych założeniach kwartałowych

Daje się zauważyć pewne tendencje do przywracania, czy też reinterpretacji na nowych zasadach estetycznych kamienicowego charakteru układów kwartałowych, tworzących pierzeje, które bazują na tradycyjnej skali podziałów. Odbywa się to jednak w nowoczesnej odsłonie architektonicznej, właściwej dzisiejszym czasom. Podstawową różnicą między historyczną a współczesną zabudową

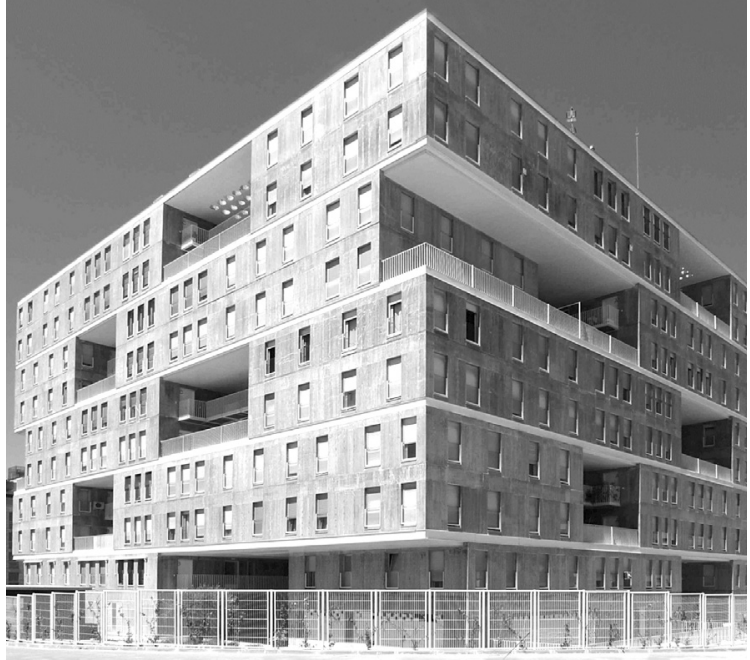

II. 4. Zinkhuset, Amerika Plads, Kopenhaga, Dania, 2008, Holsre Arkitekter $A / S$ : a) widok ogólny bryły budynku; b) kameralne wnetrze kwartału Zinkhuset, źródło/autor: P. Bigaj

III. 4. Zinkhuset, Amerika Plads, Copenhagen, Denmark, 2008, Holsre Arkitekter $A / S$, a) general view of the building; b) the intimate interior of the Zinkhuset city block, source/author: P. Bigaj II. 5. Celosia, Madryt, Hiszpania, 2009, MVRDV i Blanca Lleó, źródło/autor: P. Mika

III. 5. Celosia, Madrid, Spain, 2009, MVRDV \& Blanca Lleó, source/ author: P. Mika

tial city blocks, there are also tendencies to create geometrically rigorous facades based on the principle of axiality, as well as to introduce rhythmicity or repeatability of the elements of openings, loggias, balconies, etc., thus emphasising the expression of the planned order and neatness of the design. This phenomenon is partly related to the continuation of neo-rationalist movements, represented by such architectural figures as Aldo Rossi, Alvaro Siza, Mario Botta and Mathias Ungers. Among current rationalistic trends shaping an orderly and rigorous picture of city block architecture, one can mention such examples of buildings as the Piazza Céramique complex composed of small city blocks with roofed interiors, designed by Jo Janssen Architecte in Mastricht (the Netherlands, 2013) and La Fortezza city block by Mario Botta (Maastricht, the Netherlands, 2000) with a cylindrical form and a square courtyard interior.

\subsubsection{Restoring the "tenement" layout to housing} architecture in contemporary city blocks Currently, there are some tendencies to restore or reinterpret the tenement house character of the city blocks following new aesthetic principles, creating frontages that are based on the traditional scale of divisions. This, however, takes place in a modern architectural setting, typical of present times. The basic difference between the historical and contemporary 
estetycznym. Dla zobrazowania tendencji przywracania kamienicowego wyrazu nowej zabudowie kwartałowej mogą posłużyć duńskie zespoły mieszkaniowe, które starają się za sprawą zróżnicowania estetyczno-materiałowego i form poszczególnych segmentów tworzących pierzeje, przywołać skojarzenia tradycyjnego charakteru miejskości. Wskazać tu należy przykład zabudowy kwartałowej dzielnicy Slusenholmen (il. 6a, 6b, 6c) w Kopenhadze (Arkitema Architekst + Sjoerd Soeters, 2005-2009, Dania). Interesującym przykładem wpisującym się $w$ to zjawisko jest także budynek Le Monolithe, zrealizowany w Lyonie (Francja, 2011), gdzie na bryłę kwartału składa się pięć odmiennych estetycznie sekcji, z których każda została zaprojektowana przez innego architekta, zgodnie z planem głównym MVRDV (projekt sekcji: MVRDV, Pierre Gautier, Manuelle Gautrand, ECDM i Erik van Egeraat).

\section{Podsumowanie}

Wśród wybranych tendencji w kształtowaniu architektury kwartałów zabudowy mieszkaniowej Europy w pierwszych dekadach XXI wieku, należy wymienić zarówno te, poszukujące oryginalności rozwiązań architektonicznych, aspirujących do miana lokalnej ikony miejsca, jak i te nawiązujące do tradycyjnych podziałów kamienicowych, tworzących pierzeje w sposób nowoczesny, właściwy dzisiejszym czasom. Dają się zauważyć także pewne tendencje w samym komponowaniu elewacji poprzez swobodnie lub rygorystycznie rozmieszczane otwory, które artykułują w mniej lub bardziej czytelny sposób rozkład pomieszczeń wewnątrz budynku. Nie bez znaczenia pozostaje także materiał wykończeniowy elewacji, za pomocą którego buduje się zróżnicowany wyraz estetyczny dużych założeń kwartałowych w celu niwelowania efektu monotonności i anonimowości. Na uwagę zasługuje także rosnąca rola niedużych w skali kwartałów, tworzących kameralne wnętrza bliższe miejskim podwórzom czy dziedzińcom, czyli przestrzeniom charakterystycznym dla europejskich miast. Niektóre biura architektoniczne, jak MVRDV czy BIG, wyspecjalizowały się w poszukiwaniu nowego charakteru środowiska mieszkaniowego, opartego o interesujące idee, typologiczne i przestrzenne eksperymenty, reinterpretacje i przekształcenia znanych rozwiązań kwartałowych w nowej odsłonie estetycznej, jak i budynki hybrydowe, tworzące w ramach jednego założenia nie tylko przestrzenie do zamieszkiwania, ale i handlu, usług i rozrywki (np. Marktha/). Predestynowane do oryginalności założenia, szybko zyskują status ikon architektury mieszkaniowej i wytaczają nowe standardy jakościowe nie tylko na obszarze Europy. Wybrane tu tendencje pozwalają prognozować dalsze kierunki rozwoju idei kwartału zabudowy mieszkaniowej dla niedalekiej przyszłości. Przede wszystkim jest to powrót do tworzenia miejskich jednostek osiedleńczych w oparciu o zabudowę kwartałową, jako formę, która w najwłaściwszy sposób pozwala na tworzenie zurbanizowanych wnętrz o różnym charakterze przestrzennym. Inną cechą jest zjawisko, które można określić jako „wertykalizm” form kwartałowych, gdzie tworzy się różnego rodzaju prze- of aesthetics. Danish residential complexes can be used as an illustration of the trend of restoring the tenement house expression to the new city blocks because they try to evoke associations with the traditional character of the urban environment through the aesthetic and material diversity and forms of individual segments forming the frontage. The example of the city block in the Slusenholmen district (ill. 6a, 6b, 6c) in Copenhagen (Arkitema Architekst + Sjoerd Soeters, 2005-2009, Denmark) should be given here. Another interesting example that reflects this phenomenon is also Le Monolithe, constructed in Lyon (France, 2011), where the body of the city block consists of five aesthetically different sections, each designed by a different architect, according to a master plan by MVRDV (design of the sections: MVRDV, Pierre Gautier, Manuelle Gautrand, ECDM and Erik van Egeraat).

\section{Conclusions}

Among the selected trends shaping the architecture of European residential blocks in the first decades of the twenty-first century, one should mention both those seeking originality of architectural solutions, aspiring to the status of a local icon of a place and those referring to the traditional divisions of tenement houses, creating frontages in a modern way, typical of present times. There are also certain trends in the composition of the facade itself by means of freely or rigorously arranged openings, which articulate, in a more or less clear way, room distribution inside the building. Not without significance is also the facade finishing material that is used to create a varied aesthetic expression of large block developments in order to eliminate the effect of monotony and anonymity. Another element that deserves attention is the growing role of smallscale city blocks, creating intimate interiors closer to urban yards or courtyards, i.e. spaces characteristic of European cities. Some architectural studios, such as $M V R D V$ and $B / G$, have specialised in the exploration of the new character of the residential environment, based on interesting ideas, typological and spatial experiments, reinterpretations and transformations of familiar city block solutions presented in a new aesthetic dimension, as well as hybrid buildings, providing not only living spaces but also trade, services and entertainment (e.g. Marktha/) within a single project. Predestined for originality, they quickly gain the status of icons of residential architecture and set new quality standards that go far beyond Europe. The trends selected here allow one to forecast further development directions for the idea of a residential city block in the foreseeable future. First of all, there is a revival of the construction of urban settlement units based on a city block as the form which best allows for the creation of urbanised interiors of a different spatial character. Another feature is a phenomenon that can be described as the "verticalism" of city block forms where various types of social spaces are created-not only within the interior of the ground floor but also 
strzenie społeczne nie tylko w obrębie wnętrza parteru, ale i na wyższych kondygnacjach (np. Parkrand, Mirador). Oryginalność formy, mająca wpływ na bezpośrednie otoczenie oraz wynikająca z niej ekspresja czy ikoniczność kształtu, to jest ta cecha architektury, którą można uznać za najważniejszą w rozwoju dalszych kierunków i idei dla nowych kwartałów zabudowy mieszkaniowej.

\section{LITERATURA}

[1] Fernandez Per, A., Mozas, J., 2006, Densidad Density: New Collective Housing, Vitoria-Gasteiz: a+t ediciones.

[2] Fernandez Per, A., Mozas, J., Arpa, J., 2007, DBook: Density, Data, Diagrams, Dwellings, Vitoria-Gasteiz: a+t Density series

[3] Fernandez Per, A., Mozas, J., Arpa, J., 2009, HoCo: Density Housing Construction \& Costs, Vitoria-Gasteiz: a+t Density series.

[4] Głuchowski, M., 2015, Ku współczesnemu kwartałowi architektury mieszkaniowej. Poszukiwanie przestrzeni przyjaznej w architekturze mieszkaniowej, rozprawa doktorska, promotor: prof. dr hab. inż. arch. D. Kozłowski, Kraków: Wydział Architektury Politechnika Krakowska.

[5] Pallado, J., 2014. Zabudowa wielorodzinna: Podstawy projektowania. Gliwice: Wydawnictwo Politechniki Ślaskiej.

[6] Pallado, J., 2016, Typologia zabudowy wielorodzinnej: Teoria, dydaktyka, praktyka, Gliwice: Wydawnictwo Politechniki Śląskiej. on the upper floors (e.g. Parkrand, Mirador). The originality of form, affecting the immediate surroundings and the resultant expression or iconicity of shape, is the feature of architecture that can be considered the most significant in the development of further directions and ideas for new residential city blocks.

\section{REFERENCES}

[1] Fernandez Per, A., Mozas, J., 2006, Densidad Density: New Collective Housing, . Vitoria-Gasteiz: a+t ediciones.

[2] Fernandez Per, A., Mozas, J., Arpa, J., 2007, DBook: Density, Data, Diagrams, Dwellings, Vitoria-Gasteiz: a+t Density series

[3] Fernandez Per, A., Mozas, J., Arpa, J., 2009, HoCo: Density Housing Construction \& Costs, Vitoria-Gasteiz: a+t Density series.

[4] Głuchowski, M., 2015, Ku wspótczesnemu kwartałowi architektury mieszkaniowej. Poszukiwanie przestrzeni przyjaznej w architekturze mieszkaniowej, doctoral dissertation, supervisor: prof. dr hab. inż. arch. D. Kozłowski, Kraków: Faculty of Architecture, Cracow University of Technology.

[5] Pallado, J., 2014. Zabudowa wielorodzinna: Podstawy projektowania, Gliwice: Wydawnictwo Politechniki Śląskiej.

[6] Pallado, J., 2016, Typologia zabudowy wielorodzinnej: Teoria, dydaktyka, praktyka, Gliwice: Wydawnictwo Politechniki Śląskiej. 